\title{
REGIONALNI MANAGEMENT - IZZIV IN PREIZKUSNI KAMEN ZA POLITIKO REGIONALNEGA PLANIRANJA
}

\author{
Marjan Ravbar \\ GIAM ZRC SAZU, Novi trg 2, SI-I000 Ljubljana \\ e-mail: marjan.ravbar@zrc-sazu.si \\ Pregledni znanstveni članek \\ COBISS 1.02
}

Johan Wolfgang Göthe:

Misliti, to je enostavno, ukrepati je že težje, toda svojo misel uresničiti, to je najtežje.

\section{Izvleček}

Tudi v Sloveniji smo v zadnjem času priča razpravam o modernizaciji regionalnega planiranja. Pri iskanju sodobnih prijemov usmerjanja regionalnega razvoja ga spremlja tudi dobršna mera terminološke zmede. $\mathrm{V}$ prispevku predstavljamo novejše planerske poglede do politik regionalnega razvoja $\mathrm{v}$ teoriji in praksi. Kot podlago politikam sodobnega usmerjanja regionalnega razvoja utemeljujemo pojem »regionalnega managementa«. Z njim smo poskusili odgovoriti na naslednja vprašanja: kaj je regionalni management, kaj želimo z njim doseči in kaj so njegove temeljne naloge.

Ključne besede: Regionalni razvoj, regionalno planiranje, regionalni management, regionalni marketing, ustvarjalno okolje, učeče se regije.

\section{REGIONAL MANAGEMENT - A CHALLENGE FOR POLITICS OF REGIONAL PLANNING}

\begin{abstract}
In current time we are witnessing discussions of modernisation of regional planning. Searching for contemporary instruments for guiding regional development is accompanied by terminological confusions. The article presents contemporary planning aspect in policies of regional development in the theory and practice. The term of "regional management «, as the foundation of contemporary guiding of regional development is argued according to these questions: what is regional management, what we are trying to achieve and which are its basic tasks.
\end{abstract}

Key words: regional development regional planning, regional management, regional marketing, creative environment, learning regions. 


\section{UVOD}

V sodobni paradigmi prostorskega in regionalnega razvoja potekata dva nasprotujoča si procesa: "globalizacija" kot odraz mednarodne prepletenosti gospodarskih in političnih tokov, nasproti "drobnim" lokalnim in/ali regionalno političnim interesom, čigar cilji temelje na uravnoteženem razvoju, lokalnih ekonomijah, uravnoteženem krogotoku produkcije in surovin ter povezanosti gospodarstva $\mathrm{v}$ enotno mrežo središč. Nesporno je, da je globalizacija tako za gospodarstvo kot za politični razvoj nepovraten proces, ki se dotika celokupnega družbenega življenja, nanj vpliva in ga tudi preobraža. V zakulisju povečanega pretoka izmenjave znanja in tehnologij, internacionalizacije finančnih trgov, oblikovanja transnacionalnih podjetniških mrež (global players)... se v zadnjih letih temeljito spreminjajo tudi možnosti in načini ukrepanja na ravni regionalnih akterjev. Globalizacija je domala v vseh državah in regijah povezana s konkurenčnostjo - tekmovalnostjo ter hkrati pomeni korenite spremembe, ki jih spremljajo novi izzivi, priložnosti in tudi nevarnosti pri pospeševanju regionalnega razvoja. Konkurenčnost, oz. gospodarska atraktivnost je odvisna od vrste činiteljev. Mnogi vzroki, zlasti politični, gospodarski in splošni družbeni pogoji, leže izven samih regionalnih okvirov. Prav zato so različne sodobne zamisli pospeševanja regionalnega razvoja odsev globalizacije, in prav zato je razvojna skladnost na preizkusu. Ob tem se postavlja temeljno vprašanje: Ali je v obdobju globalizacije sploh še mogoče uspešno razvijanje metodologij in aktivnosti pospeševanja regionalnega razvoja, oziroma kakšne možnosti implementacije imajo prihodnji koncepti regionalne razvojne politike?

V Sloveniji se je s sprejetjem Zakona o spodbujanju skladnega regionalnega razvoja (1999) in pozneje uveljavljenimi dokumenti, ki so bili hkrati tudi sestavni del prilagajanja pravnemu redu $\mathrm{EZ}^{1}$ instrumentarij v planiranju regionalnega razvoja temeljito spremenil. Na novo so bili dogovorjeni postopki v planerskem procesu. Oblikovane so bile nove institucije kot npr. regionalne razvojne agencije, tehnološki parki, inovacijska središča, podjetniškoposlovne cone ... To so samo navzven opazne dejavnosti, ki razširjajo obseg delovanja ter s tem posledično postavljajo aktivnosti in metode $\mathrm{v}$ regionalnem planiranju pred nove izzive.

Sodobne metode pospeševanja atraktivnosti območij so povezane z iskanjem endogenih faktorjev in/ali s spodbujanjem ustvarjalnega okolja oz. z oblikovanjem tim. »učečih se regij«, ki jih spremljajo tudi nove pojmovne interpretacije kot so npr.: regionalni management, regionalni (urbani) marketing, procesna moderacija, komunikacijsko in mediacijsko planiranje, kooperativno razvojno pospeševanje, ipd., odpirajo popolnoma nov spekter planerskih postopkov, tako na teoretski kot tudi empirični ravni. In prav na tem torišču se odpirajo odlične možnosti povezovanja med prostorskim planiranjem in regionalnim razvojem. Regionalni management $\mathrm{v}$ tem primeru kot vmesna - intermediarna - stopnja odigrava $\mathrm{v}$ participativnih procesih ključno - posredniško - vlogo med prostorskim/regionalnim planiranjem, (podjetniškim) managementom in pospeševanjem regionalnega razvoja.

\footnotetext{
${ }^{1}$ glej npr.: Strategijo regionalnega razvoja R S, Državni razvojni program 2002-2006 - DRP in Enotni programski dokument-EPD.
} 
Regionalni management je kot institucionalizirana oblika pospeševanja regionalnega razvoja še vedno zelo mlad instrument, zato se njegovi postopki še vedno spreminjajo. Njegovi učinki pa so še vedno omejeni ter se prav zato z razvojem in empiričnimi dognanji postopno dopolnjujejo. Danes pa kljub vsemu velja za pomembno sestavino v procesu odločanja, predvsem pri sprejemanju pomembnejših prednostnih (projektnih) razvojnih nalog na srednji ravni. Regionalni management ima poudarjeno povezovalno funkcijo in s tem tvori pomembno podlago za regionalno sodelovanje različnih razvojnih akterjev (Knieling, Fürst, Danielzyk, 2003). Njegova najpomembnejša naloga je po našem mnenju povezana prav s skrbjo za prenos in uresničitev ciljev in ukrepov regionalne politike v določeni pokrajini.

Ker v slovenski planerski literaturi pojem regionalnega managementa še ni bil ustrezno ocenjen, $v$ pričujočem prispevku predstavljamo in ocenjujemo novejše planerske poglede do politik regionalnega razvoja $\mathrm{v}$ teoriji in praksi. $Z$ njim poskušamo zapolniti vrzel in odgovoriti na naslednja vprašanja: kaj je regionalni management, kaj želimo z njim doseči in kaj so njegove temeljne naloge.

\section{KRATEK PRESEK SODOBNIH METOD IN POLITIK V REGIONALNEM PLANIRANJU}

Naloga regionalne politike, kot presečišča ekonomske, socialne in prostorske politike, je pomagati gospodarsko zaostalejšim delom države. Regionalne razlike so običajno odsev naravno- in prometno-geografskih, historičnih, ekonomskih, ekoloških in upravno-političnih pogojev ter odsevajo različno izrabo človeških virov, način življenja in dela. Neenakomerna gospodarska razporeditev in narava pogojev se odražajo tudi v različni gostoti in socialnem položaju prebivalstva, v strukturi delovne sile ter infrastrukturni opremljenosti. Pod vplivom tržnih sil se namreč industrijske, trgovske, bančne, zavarovalniške in druge gospodarske dejavnosti, s tem pa tudi ustvarjalno okolje, izobraževanje in kultura ter preostala družbena infrastruktura kopičijo v razvitejših okoljih. Na tej podlagi temelji privlačnost regije in njen položaj v okviru narodnega in globalnega gospodarstva.

Neizenačenost življenjskih pogojev in želja po gospodarskem integriranju celotnega državnega teritorija narekuje oblikovanje takšnih politik, ki naj bi vsem prebivalcem omogočile primerljive razmere za življenje in delo.

Začetno obdobje uveljavljanja regionalne politike v drugi polovici prejšnjega stoletja je temeljilo na klasičnih principih državnega poseganja. Takšna regionalna politika je bila usmerjena v odpravljanje nerazvitosti s subvencioniranjem kapitala in ustvarjanjem novih delovnih mest (pretežno)v industriji in za (pretežno nekvalificirano) delovno silo ter v posodabljanje infrastrukturne (komunalne) opremljenosti območij. V ta namen so bili izoblikovani posebni instrumenti, ki so zajemali tudi denarne podpore industrijskim podjetjem, kredite s subvencionirano obrestno mero, olajšave davčnih in socialnih prispevkov, naložbe v infrastrukturo, subvencioniranje transportnih stroškov... Problemska območja so določili s pomočjo izbranih enotnih kazalnikov. Politika pospeševanja se je v prvem obdobju izkazala kot uspešno. Čeprav so bile razlike med posameznimi državami znatne, je bil temeljni pristop povsod v Evropi podoben. 
Medtem ko je bila prvotna politika pospeševanja gospodarskih aktivnosti posledica klasičnih lokacijskih prednosti (surovine, energetski viri, prometni položaj...), sloni sodobna politika regionalnega razvoja na pospeševanju izobrazbene ravni delovne sile, razvijanju modernih komunikacijskih sistemov, razvojno-raziskovalnih potencialov ter vsem ostalem, kar daje geografskemu okolju “prijazen" značaj. Z ustrezno izobrazbeno strukturo prebivalstva (in kapitala) se oblikuje ustvarjalno okolje, ki praviloma tvori prostorsko zaključeno skupnost, pri čemer so administrativne meje manj pomembne oz. ne predstavljajo nekega posebnega "razpoznavnega" kriterija. Pomembnejši vzvodi so homogenost v načinu ravnanja in zmožnost prilagajanja. Poglavitne metodološke razlike v pristopih na modelni ravni prikazuje spodnji pregled.

Preglednica 1: Poglavitne razlike med klasičnimi in sodobnimi pristopi v regionalnem planiranju

Table 1: Basic difference between classic and contemporary approach in regional planning

\begin{tabular}{|c|c|}
\hline klasična regionalna politika: & inovativna regionalna politika: \\
\hline $\begin{array}{c}=\quad \text { nudenje pomoči na podlagi klasičnih } \\
\text { produkcijskih in lokacijskih faktorjev }\end{array}$ & $\left.\begin{array}{l}=\text { socialno in kulturno okolje } \\
=\text { oblikovanje regionalnih omrežij }\end{array}\right\} \begin{array}{l}\text { ustvarjalno } \\
\text { okolje }\end{array}$ \\
\hline $\begin{array}{l}\text { - } \text { prometna in energetska infrastruktura; } \\
\text { - komunikacijska infrastruktura; } \\
\text { - } \text { preskrba in oskrba; } \\
\text { - izobraževalna in zdravstvena } \\
\text { infrastruktura; } \\
\text { - ponudba površin za industrijo in obrt; } \\
\text { - pospeševanje komunalne opremljenosti; } \\
\text { - itd. }\end{array}$ & $\begin{array}{l}\text { - } \text { tehnološki transfer (izmenjava informacij); } \\
\text { - } \text { odprtost in zaupanje; } \\
\text { - } \text { podjetniško svetovanje; } \\
\text { - } \text { mobilnost delovne sile; } \\
\text { - regionalna identiteta; } \\
\text { - institucionalna opremljenost (sponzorstvo); } \\
\text { - visoki potenciali za rekreacijo in prosti čas; } \\
\text { - različne socialne aktivnosti; } \\
\text { - visoka stopnja neonesnaženosti okolja; } \\
\text { - visoko postavljeni standardi kvalitete življenja; } \\
\text { - kultura upravljanja. }\end{array}$ \\
\hline
\end{tabular}

Vir: priredba po Fromhold-Eisebith, M. (1995).

»Regionalna politika je, po svojem namenu, temeljno orodje za dolgoročno in usklajeno usmerjanje prostorskega in regionalnega razvoja ter pomeni doseženo stopnjo soglasja o temeljnih problemih in ciljih usmerjanja regionalnega razvoja na državni, pokrajinski in lokalnih ravneh z upoštevanjem aktualnih evropskih povezav. Regionalna in prostorska politika tvorita okvir prizadevanjem za tržno gospodarsko učinkovitost, socialno pravičnost in ekološko sprejemljivost razvoja, ki morajo spoštovati pravni red države, kulturno samobitnost naroda in življenjske interese vseh državljanov. S pospeševanjem regionalnega razvoja skušamo odpraviti ali vsaj ublažiti posledice tržnega gospodarstva, ki povzročajo regionalne razlike med različnimi območji in zaradi katerih nekateri deli uživajo prednosti, drugi pa so zapostavljeni in njihov razvoj stagnira ali celo nazaduje².

\footnotetext{
${ }^{2}$ Marsikje gre za drobna in svojstveno zaokrožena območja, ki jih posebej zaznamujejo naravno geografske specifičnosti in imajo "odsev" tudi v družbeno geografskih prilikah.
} 
Preglednica 2 : Paradigme regionalne politike v preteklosti in sodobnosti

Table 2: Paradigms of the past and contemporary regional policy

\begin{tabular}{|c|c|c|}
\hline Značilnosti & Klasična & Moderna \\
\hline Cilj: & $\begin{array}{l}\text { Nova delovna mesta, nove } \\
\text { investicije... }\end{array}$ & $\begin{array}{l}\text { Izboljšana konkurenčnost (podjetništvo, inovacije, } \\
\text { znanje) }\end{array}$ \\
\hline $\begin{array}{l}\text { Teoretske } \\
\text { podlage: } \\
\text { oporne točke }\end{array}$ & $\begin{array}{l}\text { Lokacijska teorija: ključni } \\
\text { faktorji razvoja so proizvodni } \\
\text { stroški in razpoložljivost } \\
\text { delovne sile } \\
\text { Lokacijski faktorji: bližina } \\
\text { surovin, trga in oskrbovalcev, } \\
\text { ustvarjanje novih delovnih mest } \\
\text { (diverzifikacija) }\end{array}$ & $\begin{array}{l}\text { Teorije »učečih se« regij: ključni faktorji so } \\
\text { ustvarjanje dodane vrednosti, inovacijsko okolje, } \\
\text { decentralizacija proizvodnje (rast industrijskih } \\
\text { »clustrov«), večanje stroškov v središčih, stare } \\
\text { industrije se selijo v območja z nižjimi stroški, } \\
\text { specializacija novih proizvodenj, prisotnost } \\
\text { raziskovalnega instrumentarija; spoštovanje } \\
\text { trajnostnega razvoja }\end{array}$ \\
\hline $\begin{array}{l}\text { Namen: } \\
\text { Enakomernost in } \\
\text { učinkovitost } \\
\text { Analitična osnova: } \\
\text { Ključne } \\
\text { aktivnosti: }\end{array}$ & $\begin{array}{l}\text { Pospeševanje infrastrukturne } \\
\text { opremljenosti in ustanavljanje } \\
\text { posameznih industrijskih } \\
\text { obratov } \\
\text { Kazalniki stopnje razvitosti } \\
\text { Pomoč podjetjem, trda } \\
\text { infrastruktura }\end{array}$ & $\begin{array}{l}\text { Pospeševanje inovacijskih procesov, (npr. } \\
\text { "grozdenje", medsektorska koordinacija... } \\
\text { SWOT analize regij, regionalni “foresight" } \\
\text { Razvojni program, poslovno okolje, mehka } \\
\text { infrastruktura... }\end{array}$ \\
\hline $\begin{array}{l}\text { Organizacija } \\
\text { določanja politik } \\
\text { Ključna institucija }\end{array}$ & $\begin{array}{l}\text { razvojni impulzi: centralizirano } \\
\text { (»top-down«) } \\
\text { Centralna oblast }\end{array}$ & $\begin{array}{l}\text { Kolektivno - partnersko: od spodaj navzgor } \\
\text { (»botom up«); podjetniško, inovativno... } \\
\text { Decentralizacija, prehod na regionalno raven, } \\
\text { obnovljena vloga regionalnega planiranja, poudarek } \\
\text { na kvaliteti življenja }\end{array}$ \\
\hline $\begin{array}{l}\text { Regionalna } \\
\text { politika: } \\
\text { značilnosti }\end{array}$ & $\begin{array}{l}\text { Problemska območja: gorska, } \\
\text { kraška, obmejna območja... } \\
\text { Zmanjševanje regionalnih } \\
\text { disparitet, izenačevanje med } \\
\text { regijami }\end{array}$ & $\begin{array}{l}\text { Homogenost območij: referenčni okvir za } \\
\text { programski in projektni razvoj vseh regij. } \\
\text { Uravnotežena tekmovalnost med regijami s } \\
\text { pomočjo inovacij }\end{array}$ \\
\hline Partnerstvo & ga ni & $\begin{array}{l}\text { Krepitev raziskovanja (»privatno-javno } \\
\text { partnerstvo«), lokalna združenja, nevladne } \\
\text { organizacije, socialni partnerji, ... }\end{array}$ \\
\hline Administracija & $\begin{array}{l}\text { Enostavna/racionalna: } \\
\text { pospeševanje razvojnih } \\
\text { konceptov, potrjevanje in } \\
\text { sofinanciranje posameznih } \\
\text { projektov }\end{array}$ & $\begin{array}{l}\text { Kompleksna/razvojna: pospeševanje "clustrov" } \\
\text { in mrežnih projektov, podpora "pilotnim" in } \\
\text { inovativnim projektom na podlagi predhodno } \\
\text { določenih pravil, monitoring in evalvacija; }\end{array}$ \\
\hline Izbor projektov & Notranji & Participativen \\
\hline Časovni okvir & "Petletka" & Večletna razvojna perspektiva (šest let) \\
\hline Vrednotenje & zaključno (ex-post) & Predhodno, vmesno, končno \\
\hline Rezultati: & $\begin{array}{l}\text { Težko merljivi, še posebej } \\
\text { kratkoročno }\end{array}$ & Merljivi \\
\hline
\end{tabular}

Vir: Priredba po: Neue Regionalpolitik, Schlussbericht, 2001 in Bachtler John, Yuill Douglas, 2001. str. 12

Vzroki za ta gibanja so različni: zgodovinski razvoj, privlačnost za naložbe, prometni položaj, obmejna lega, uvajanje inovacij (zlasti tehniških in tehnoloških), socialne razmere, samogibno 
kopičenje prednosti, ki jih prinašajo velike naložbe na določeni lokaciji, pa tudi družbena in psihološka naravnanost za uvajanje novosti in dosego napredka. Regionalne razlike torej ustvarjajo neutemeljeno razlikovanje med posameznimi območji, ki gre v končnih posledicah na škodo celotne družbene skupnosti. Povzročajo tudi politične probleme, ki se jim skušajo v naprednih družbah izogniti s premišljeno razvojno politiko in z njo uveljaviti sprejeto družbeno načelo »o enakih možnostih ne glede na kraj prebivališča«. Regionalne disparitete povzročajo medregionalne migracije delovne sile, saj se predvsem mlajša in izobražena delovna sila izseljuje iz manj razvitih območij (Ravbar, 1998). Medregionalne razlike v sestavi proizvodnje, višini dohodka na prebivalca, stopnji zaposlenosti, mobilnosti in starostni strukturi prebivalstva so poglavitni razlog za nastanek problemskih območij. Mednje uvrščamo pretežno agrarna območja, območja s tehnološko zaostalo industrijo (ki so praviloma tudi z okoljskega vidika degradirana) in visoko stopnjo brezposelnosti ter težje dostopne in obmejne regije. Skušnje kažejo, da je odpravljanje regionalnih razvojnih razlik težavno, drago in počasno. Ni mogoče pričakovati hitrih in bleščečih uspehov. Zaradi tega je treba sprotno vrednotiti uspešnost razvojne politike in ob tem ugotavljati, kakšna so regionalna razvojna gibanja, problemi ter kako nadaljevati« (Vrišer, 1999).

Ziskanjem kompleksnih vsebin in faktorjev inovativno naravnanega regionalnega razvoja seže dalj časa ukvarjajo ekonomisti, gospodarstveniki, geografi, sociologi in regionalni planerji. Klasične raziskave, ki so dotlej opozarjale na pomen regionalne opremljenosti in prikazovale gospodarsko strukturo, ponudbo storitvenih dejavnosti, prisotnost visoko produktivnih dejavnosti ("venture capital"), prometno povezanost, kvaliteto življenjskega okolja, itd. nadomeščajo novi pogledi vrednotenja odnosov znotraj same regionalne skupnosti. Za to se v številnih razpravah uporablja pojem "ustvarjalno okolje" (»kreativni milje«), ki je sinonim za intenzivno povezovanje znanstveno - tehnoloških centrov z ostalimi gospodarskimi omrežji in ima pomembne prostorske implikacije na regionalni ravni (Aydalot, 1986, Maillat, 1992). Po svoje je to nov pogled in temu je prilagojena svojstvena, vendar sodobna interpretacija vsebin regionalnega planiranja.

\section{REGIONALNI MANAGEMENT IN REGIONALNI MARKETING - NOVA INSTRUMENTA V REGIONALNEM PLANIRANJU}

Številne teoretske in empirične raziskave ter tudi rezultati kažejo, da je tradicionalistični sistem pospeševanja regionalnega razvoja, kljub neizpodbitnim uspehom, še vedno premalo učinkovit. Med poglavitnimi razlogi za slabo učinkovitost moramo poudariti odsotnost potrebne koordinacije med ukrepi regionalne in drugih politik (industrijska, zaposlitvena, kmetijska in druge), saj različne sektorske strategije običajno postavljajo regionalno planiranje $\mathrm{v}$ podrejen (defenziven) položaj in posvečajo prednost sledenju (pre)ozkim sektorskim zamislim. Pomembno dejstvo je tudi, da ekonomska in tudi regionalna politika premalo upoštevata sinergijske razlike med naravnimi pogoji in človeškimi potenciali posameznih regij ter tudi nekatere druge "neekonomske" faktorje (Ravbar, 2000).

Prav zato smo tudi v Sloveniji v zadnjem času priča razpravam o modernizaciji regionalnega planiranja, ki jo spremlja tudi dobršna mera terminološke zmede pri iskanju sodobnih 
(uspešnejših) prijemov usmerjanja regionalnega razvoja. $\mathrm{S}$ tem, ko je regionalna politika postala nacionalna razvojna politika, se regionalnim razvojnim programom, njihovemu spremljanju oz. implementaciji politik pripisuje vse večji pomen: tako je npr. v uredbi, ki se nanaša na strukturne sklade ${ }^{3}$, spremljanje izvajanja programov urejeno v posebnem poglavju. Glavna posledica teh novosti je poleg odgovornosti za uveljavljanje in spremljanje programov na merljivi stopnji in s tem primerljivosti poglavitnih ciljev, tudi iskanje sodobnih in učinkovitejših instrumentov za dejansko izvedbo. Napori so torej povezani s prizadevanji dveh medsebojno povezanih poti: na eni strani z izborom ustreznih kazalnikov spremljanja ${ }^{4}$ in na drugi strani z implementacijo programskih ciljev.

V nadaljevanju se posvečamo predvsem prenosu ciljev regionalnih politik. V tej povezavi sta se v zadnjem desetletju uveljavila predvsem dva sodobna instrumenta, ki prinašata veliko novosti $\mathrm{v}$ obstoječe planerske postopke: regionalni marketing in regionalni management, katerih poglavitno povezanost in primerljivost $\mathrm{s}$ konvencionalnimi pristopi prikazuje spodnja preglednica.

\section{Preglednica 3: Primerjava med sistemi v konvencionalnem planiranju in sodobnimi instrumenti}

Table 3: Comparison of the systems of conventional and contemporary planning instruments

\begin{tabular}{|l|l|l|}
\hline Postopki v konvencionalnem planiranju & $\Leftrightarrow$ & \multicolumn{1}{|c|}{ Moderni instrumenti } \\
\hline Cilj = regionalni razvojni program & $\Leftrightarrow$ & Cilj= dogovorno - »pogajalsko« planiranje \\
\hline Presečno, (deloma) omejevalno & $\Leftrightarrow$ & Konstruktivno razvojno planiranje \\
(prostorsko) planiranje & $\Leftrightarrow$ & Prepričevalno planiranje \\
Legalistično planiranje $^{5}$ & $\Leftrightarrow$ & Procesno naravnano planiranje \\
V dobičkonosnost usmerjeno planiranje & $\Leftrightarrow$ & \\
Nizka stopnja uresničevanja programa & $\Leftrightarrow$ & Uresničitvena naravnanost \\
Upravno - pravno ravnanje & $\Leftrightarrow$ & Planerski management \\
Zagotavljanje formalističnih postopkov & $\Leftrightarrow$ & Moderacijski-/komunikacujski postopki \\
Hierarhično razreševanje konfliktov & $\Leftrightarrow$ & Razumsko razčiščevanje problemov \\
Načelo »protitoka« ${ }^{6}$ & $\Leftrightarrow$ & Načelo soglasja \\
Teritorialno določevanje razvojnih & $\Leftrightarrow$ & Problemsko oblikovanje razvojnih območij \\
območij & & Neformalna (»plitva«) omrežja vplivnih \\
Demokratična legitimacija teritorialnih & & območij \\
območij & & \\
\hline
\end{tabular}

Vir: priredba po: Wiechmann (1998).

\footnotetext{
${ }^{3}$ Council Regulation (EC) No 1260/1999 of 21 June 1999 laying down general provisions on the Structural Funds, Official Journal of the European Communities, 26. 6. 1999.

${ }^{4}$ več o tem: Ravbar, Nared, 2003

5 = natančno določen regionalno planerski postopek;

${ }^{6}$ Načelo "protitoka" je značilen izraz v prostorskem planiranju, ki izraža željo po usklajenem urejanju celotnega območja regije nasproti upoštevanju potreb nekaterih delov za hitrejšim razvojem. Principom "protitoka" se izognemo s principi subsidiarnosti.
} 
Med instrumenti regionalnega planiranja ima pomembno vlogo tudi sam postopek. Z njim ni povezana zgolj formalistična podlaga za uveljavitev in za izvajanje plana $\mathrm{v}$ določeni pokrajini in časovnem obdobju, marveč sta instrumentalna in postopkovna funkcija povezani tudi z vprašanjem, kako doseči temeljni konsenz, s katerimi bomo uravnavali regionalni in prostorski razvoj določene pokrajine. Gre torej hkrati za vsebinska in instrumentalna vprašanja, povezana predvsem s "sporočilno izpovedjo", ki ju nikakor ne smemo zanemariti. In prav z razreševanjem teh temeljnih dilem so povezani sodobni pripomočki za oblikovanje konceptov regionalnega planiranja.

Dosedanje empirične raziskave sicer nakazujejo različne uspešne poti pospeševanja regionalnega razvoja predvsem s pomočjo ustvarjalnosti, iskanjem soglasij med nosilci razvoja in ostalimi udeleženci, kot tudi z uravnavanjem pristojnosti. Na podlagi nakopičenih problemov pri prenosu razvojnih konceptov v prakso pa postajo vedno glasnejši tudi pozivi $\mathrm{k}$ oblikovanju projektno naravnanih instrumentov. To se dogaja zgolj zato, ker sodobni izzivi pospeševanja regionalnega razvoja niso več v popolnosti kos zastavljenim ciljem, ne $\mathrm{v}$ državnih in tudi ne $\mathrm{v}$ regionalnih razvojnih programih. S pomočjo novih instrumentov pa je mogoče relativno abstraktno zasnovane cilje zapisane $\mathrm{v}$ regionalnih razvojnih programih konkretizirati, razvojna hotenja regionalnih nosilcev pa natančneje določiti in z okoljsko uravnoteženega vidika tudi konsezualno umestiti v prostor. Visoka stopnja konkretizacije pa zahteva tudi podrobnejše informacije in boljšo informiranost prizadetih. Merilo uspešnosti je odvisno od stopnje prenosa v prakso in prav zato se zdi, da sta lahko »regionalni management« in/ali »regionalni marketing« ustrezna instrumenta za implementacijo ciljev regionalnega razvoja.

Ta dva pojma sta se v planerski literaturi v zadnjih letih tudi najbolj uveljavila. Po mnenju pisca pričujočih razmišljanj, morda samo poimenovanje niti ni najbolj posrečeno izbrano, saj zaradi močnih asociacij s podjetništvom lahko sproža številne dvome in prav zaradi tega je moč pospeševanje določene pokrajine navidez razumeti kot neke vrste podjetniško zasnovan »koncern«. Pogled v dostopno literaturo nam še pokaže, da zaenkrat še vedno ni vsesplošno priznane in sprejemljive definicije za nobenega izmed pojmov (Giessendorfer, Rahn, Stoiber, Meier, Siebert, 2003).

Še pred poskusom pojmovne opredelitve obeh sodobnih instrumentov je potrebno poudariti, da pomembnejših razlik med pojmoma »regionalni marketing« in »regionalni management«, ter tudi ne s sorodnimi izrazi kot so npr: »planerski marketing« in »planerski management«, pa tudi »urbani marketing« ... pravzaprav ni. Regionalni marketing ima za cilj posredovanje planerskih vsebin javnosti, razvojnim akterjem in neposredno prizadetim ljudem. V ožjem pomenu ga je razumeti tudi kot instrument, čigar namen je pospeševanje sodelovanja med regionalnimi akterji. Regionalni management pa v primerjavi z marketingom vsebuje še različne vidike vzpostavitve vodenja planerskih postopkov. Njegovi metodološki vzvodi so usmerjeni v iskanje instrumentov, za dajanje ustreznih pobud in vodenje presečno naravnanih regionalnih razvojnih procesov s pomočjo kvalificiranih strokovnih podlag. Za oba sodobna instrumenta še velja, da sta del regionalnega planiranja ter v sebi združujeta zelo kompleksno zasnovane postopke vodenja regionalne politike, čigar poglavitna skrb jima je prenos regionalno-programskih ciljev v prakso. 


\section{Regionalni marketing}

se je kot instrument regionalnega planiranja etabliral že v začetku 90- let dvajsetega stoletja. Po Bühlerju (1997) ga je razumeti kot presečno in postopkovno naravnan komunikacijski instrumentarij $\mathrm{v}$ regionalnem planiranju za dolgoročno doseganje konkurenčnosti in zmožnost uveljavitve prostorske in ekonomske atraktivnosti določenega geografskega okolja oz. dolgoročno krepitev posameznih delov regionalnih (krajevnih) privlačnosti. Regionalni marketing še zlasti poudarja učinkovito izkoriščanje razpoložljivih resursov, med ostalim mu avtor namenja še posebno vlogo pri identifikaciji regionalnih posebnosti in skrbi za sproščanje regionalnih potencialov.

Kot tipične aktivnosti, ki določajo regionalni marketing so povezane s projektno usmerjenostjo za prenos znanja v določeno geografsko okolje, celovitost planerskih aktivnosti, presečno naravnanost pri iskanju konsenza med nasprotujočimi se interesi, izkoriščanje lokalnih potencialov, medsebojno sodelovanje, grozdenje ekonomskih akterjev, medsebojne komunikacije, prostovoljnost... Prav tako kot podjetniški marketing, tudi regionalni marketing stremi k dvema smotroma: navznoter naravnani regionalni zavesti in občutku samozavesti prebivalstva h krepitvi lastne samoprepoznavnosti. V nasprotju s klasičnim marketinškimi prijemi pa poskuša regionalni marketing svoje lastne potenciale predstaviti navzven kot zunanjo učinkovitost. Sem sodi zlasti razvoj pozitivne prepoznavnosti lastne podobe regije navzven s ciljem pospeševanja atraktivnosti za neposredne tuje investicije. Posledično vsebuje še cilj vzpodbujanja nove gospodarske moči v regiji. Cilje regionalnih marketinških iniciativ lahko strnemo v naslednje aktivnosti (Gorlik, 1999):

- Krepitev/izboljšanje konkurenčnosti in krajevne atraktivnosti območij, npr. za spodbujanje investicij, pa tudi za naseljevanje prebivalstva (zunanji marketing),

- ॥Senzibilizacija« prebivalstva in gospodarstva, ki zadevajo prednosti območja (notranji marketing)

- Profilacija, pozicioniranje in predstavitev območja navznoter in navzven,

- Dvig stopnje poznavanja lastnih regionalnih zakonitosti, prednosti in priložnosti,

- Pospeševanje gospodarskega sodelovanja in povezovanja znotraj regije,

- Ustvarjanje pozitivnega gospodarskega in investicijskega vzdušja,

- Pridobivanje novih investitorjev v regionalnem okolju,

- Skrb za razvoj endogenih potencialov,

- Skrb za ustvarjalno okolje, ustvarjanje regionalne zavesti in krepitev regionalne identitete.

- Pospeševanje ustvarjalnosti in inovacij za razvijanje regionalnih prednosti in s tem zmanjševanje lastnih slabosti

Ob sklepu poskusa opredelitve temeljnih značilnosti regionalnega marketinga velja še poudariti njegovo skupno značilnost, ki je v tem, da je razumljen kot dolgotrajen učni proces, kjer se njegova empirična vrednost postopoma izgrajuje $\mathrm{v}$ vsakem geografskem okolju posebej $\mathrm{s}$ pomočjo različnih poudarkov in se uporablja prilagodljivo na podlagi specifičnih regionalnih značilnosti.

\section{Regionalni management}

Cilj regionalnega managementa je povečevanje dodane vrednosti in racionalno izkoriščanje regionalnih potencialov. Zato ga ne gre ga zamenjevati z regionalnim marketingom. Regionalni 
management pomeni oblikovanje, vodenje in izvrševanje razvojnih zamisli, temelječih predvsem na naslednjih razvojnih faktorjih: na človeških virih (»human resources«), ustvarjalnem okolju (»les milieux creatives«), mrežnem povezovanju (»Network/Cluster«), soglasju (konsenzu) in sodelovanju prizadetih. Pomembna novost je še v konceptualni naravnanosti, usmerjeni v prenos razvojnih aktivnosti (s pomočjo projektne naravnanosti) v pokrajino ali njene dele, pri čemer igra odločujočo vlogo presečna povezanost posameznih dejavnosti resorjev (Troeger-Weiss, 1998).

Najpomembnejša naloga regionalnega managementa je v skrbi za prenos ciljev, projektov in ukrepov regionalne politike $\mathrm{v}$ določeni pokrajini, ki izhajajo iz (regionalnih) razvojnih programov. V bistvu gre za enostavno, vendar medsebojno povezano oblikovanje ciljev in njeno implementacijo. Vsak cilj je posledično povezan s konkretno realizacijo projekta in obratno, vsak projekt temelji na vnaprej oblikovanih ciljih. Regionalni management pa v tem primeru ne pomeni zgolj "vodenje" neke regije in njenih "udeležencev" v hierarhičnem smislu, marveč se s pomočjo posebih metod vodenja, ki vodijo k sprejetim ciljem, zavzema za procesirano součinkovanje (sodelovanje) vseh regionalnih akterjev, čigar prenos razvojnih konceptov generira nove projektne ideje, ki v končni konsekvenci pomenijo uspešno pozicioniranje podjetništva $\mathrm{v}$ sami regiji ter s tem plasiranje večje razpoznavnosti določenega geografskega okolja v pogojih globalizacije oziroma v tekmovanju regij. Poslužuje se sodobnih planerskih postopkov kot sta moderacija, ali mediacija v planerskem procesu. Regionalni management poskuša med razvojnimi procesi izluščiti ključne in inovativne probleme regionalnega razvoja, medtem ko planerski management vztraja na klasičnih instrumentih prostorskega planiranja.

Zahteve so običajno visoko postavljene, ne le na področju ekonomskih aktivnosti, marveč še posebej na področju socialnih pristojnosti, ki jim je potrebno posvečati posebno pozornost. Poudarek je še pri koordinaciji velikega števila samostojnih regionalnih akterjev. Takšni udeleženci so praviloma lokalne skupnosti, privatni akterji, podjetja in javne institucije. Poleg same vsebine je ravno tako pomembna koordinacija in konkretizacija projektov $\mathrm{v}$ povezavi s političnimi nosilci odločanja, strokovno javnostjo, prizadetimi nosilci odločanja in prebivalci.

Regionalni management s svojimi instrumenti pospešuje razvojne procese kot npr:

- Razvijanje integriranih regionalnih razvojnih konceptov in predvsem njihovo uresničitev

- Identifikacijo in sprožanje razvojnih konceptov v tek na podlagi konsenza med regionalnimi akterji

- Pospeševanje in izgradnja regionalnih omrežij, alians, povezovalnih projektov, inovacijskih klastrov...

- Mobilizacija prikritih zaposlitvenih in razvojnih potencialov (Obermaier, 1996).

V praksi pojem regionalnega managementa v sebi združuje tri temeljne zamisli (Becker, Ekert, 2004). Prva vsebuje »kolektivno« razvojno vizijo, ki je oblikovana kot regionalni akcijski načrt in vsebuje strokovne, strateške in taktične zamisli pospeševanja $\mathrm{z}$ vidika razvojnih perspektiv upoštevajoč regionalne potenciale in ključne razvojne probleme z vidika izboljšanja gospodarskih, socialnih in okoljskih razmer, konkurenčnosti pokrajine nasproti sosednjim regijam, eksterne omejitvene možnosti, npr. finančne omejitve ... Te naloge je potrebno permanentno preverjati na temeljih novih projektnih idej in na novo identificiranih 
razvojnih potencialov ali spremenjenih finančnih možnosti ter jih po potrebi tudi spreminjati. Drug sklop je usmerjen k spremljanju in podpori ključnim regionalnim projektom, čigar realizacija je odločujočega pomena za regijo. Naloga regionalnega managementa je v tem primeru v odkrivanju vzrokov ev. odstopanj pri morebitnih neustreznih projektnih postopkih. Tretja naloga pa je povezana $\mathrm{z}$ dajanjem in usmerjanjem pobud za nove inovativne projekte. $\mathrm{V}$ tem primeru gre prvenstveno za mobilizacijo regionalnih akterjev in potencialov, kjer imajo pomembno vlogo organizacijski in pospeševalni elementi, z namenom da se ključni razvojni projekti medsebojno povežejo in tudi zaključijo. $\mathrm{V}$ tej povezavi je potrebna sistematična izgradnja komunikacijskih-, informacijskih in delovnih struktur, ki so nujno potrebne $\mathrm{v}$ funkciji sprotnega zaznavanja novih inovativnih idej, ki jih izžarevajo regionalni akterji.

\section{VLOGA REGIONALNEGA MANAGEMENTA PRI SODELOVANJU IN/ALI KONKURENČNOSTI REGIJ}

Sodelovanje in konkurenčnost sta dve plati iste medalje, ki ju povezuje regionalni management. Poleg prizadevanj po sodelovanju so v pogojih globalizacije praviloma vedno bolj prisotne tudi težnje po tekmovalnosti: »Obstoj tekmovalnosti na vseh pokrajinskih ravneh - tudi med partnerji znotraj enotne mestne regije - postaja v sodobnosti dejstvo« (Sturm, 2000). Pod pritiski uravnotežene tekmovalnosti - konkurenčnosti pa pridobiva na pomenu predvsem sodelovanje. Presečne povezave med kooperacijo ${ }^{7}$ in konkurenčnostjo regij ${ }^{8}$ so tesne pri čemer jima je skupni imenovalec prav ustvarjalnost. Pri kooperaciji pa gre dodatno le še za razširitev stremljenj in za razširitev sodelovanja, kakršno ponuja tekmovalnost. Konkurenca je torej odločujoč činitelj za regionalno kooperacijo s pomočjo instrumentov regionalnega managementa (Bergmann, Jakubowski, 2001).

Za uspešno implementacijo odnosov uravnotežene konkurenčnosti je zelo pomembna gospodarska usmerjenost - specializacija mest ali posamezne regije, ki običajno ustvarja značilen vzorec medsebojnih prepletov - »cluster« oz. »network«. Lastnosti le-teh pa so običajno povezane $\mathrm{z}$ :

- Mednarodno izmenjavo znanja in tehnologij ...,

- Številom tujih podjetij, kar se izraža z neposrednimi tujimi investicijami,

- Izgrajevanjem regionalnega/transnacionalnega omrežja gospodarskih združenj ...,

- $\quad$ Socialno - ekonomskim okoljem (Lucas, 2000).

\footnotetext{
${ }^{7}$ kooperacijo označujemo kot gonilno silo v regionalnem managementu z več vidikov: (1) s strateško-političnega vidika kot preprečevanje medsosedskih konfliktov, poglobitev medsebojnih socio-kulturnih vrednot, krepitev kulturne in regionalne identitete ter socialne in teritorialne kohezije. (2) z razvojno-političnega vidika pa kot pospeševanje gospodarskih prepletanj, izrabo skupnih resursov in optimiranja infrastrukturne opremljenosti,...

${ }^{8}$ uravnotežena konkurenčnost označuje jasno formulirana strateška prizadevanja politikov in prostorskih planerjev za pozicioniranje regij $\mathrm{v}$ evropskem naselbinskem sistemu na podlagi zajetne analize lokalnih priložnosti in slabosti regij in/ali celotnega vplivnega območja mestne regije.
} 
Pri tem je priporočljivo, da regionalna politika zasleduje najmanj tri principe, ki izvirajo iz interakcijske ekonomike. Ti so po Suchananeku (2000): (1) realizacija družbenih ciljev, ki jih prinašata sodelovanje in konkurenčnost ter načeli (2) spodbujanja samouravnavanja endogenih potencialov in (3) institucionalizacija aktivnosti pri izvedbi prednostnih projektov uravnotežene konkurenčnosti.

Pri doseganju družbenih učinkov konkurenčnosti je za vsako sodelovanje neobhodno upoštevanje interesov vseh partnerjev. Kajti vsako tekmovalnost regij/mest istočasno označujejo poleg skupnih, še nasprotujoči se interesi (borba vseh proti vsem) in na takšna nasprotovanja mora biti regionalno planiranje tudi pripravljeno, ki mora poleg svojih lastnih koncepcionalnih in urejevalskih metod krmiliti še med aktualnimi robnimi pogoji kot so globalizacija, deregulacija institucij ...

Uravnotežena konkurenčnost ima torej skupaj z regionalnim managementom potemtakem zgolj instrumentalni značaj. Je sredstvo za doseganje določenega namena. Gospodarskim združenjem pomaga preskrbeti prednosti pred konkurenti in s tem deluje v kolektivnem duhu večine zainteresiranih. Vsak princip uravnavanja mora namreč upoštevati interese različnih akterjev. Izhaja iz omejenosti (naravnih in človeških) virov ter zasleduje izvedljive razvojne in projektne možnosti in je v svojem bistvu namenjena preprečevanju konfliktov s ciljem spoštovanja poznanih oblik, socialne interakcije v duhu kooperacije. Smisel konkurenčnosti je pospeševanje kooperacije. »Produktivna je le tista konkurenčnost, kjer tekmeci konkurirajo s svojim znanjem in te svoje prednosti posredujejo na trgu. Na drugi strani pa je učinek konkurenčnosti v selekcijskem posredovanju dobrin, in te okoliščine silijo konkurente in njihove dosežke k nadaljnjemu izpopolnjevanju« (Suchanek, 1998).

\section{SKLEPNA RAZMIŠLJANJA}

Usmerjanje regionalnih razvojnih procesov ima posebne zahteve pri optimiranju in pospeševanju lastnega notranjega razvoja. In zakaj je v tem primeru potreben nov instrument? Zato obstaja več razlogov za nadaljnje razvijanje metod in vsebin v regionalnem managementu. Le nekaj primerov:

- V prihodnje je pričakovati vse manj eksternih impulzov v regionalnem razvoju ${ }^{9}$, zato postaja izkoriščanje endogenih potencialov vse pomembnejše,

- Tradicionalne strukture obstoječega politično-administrativnega sistema tudi običajno niso pripravljene teh potencialov v polni meri podpirati. Pogosto je odsotna socialnotehnična kompetentnost in akceptanca, da bi se regionalni akterji medsebojno povezali in $\mathrm{s}$ tem $\mathrm{z}$ aktivnejšim sodelovanjem spodbudili nov razvojni vzpon,

- Napet finančni položaj lokalnih skupnosti in omejene možnosti pridobivanja finančnih spodbud bodo zahtevale osredotočenje na izbrane (regionalne) razvojne projekte. To posledično povišuje stopnjo pripravljenosti (uskladitev interesov) za strateško odločanje (glede na optimizacijo regionalnega razvoja), ki priobstoječem politično-administrativnem sistemu ni vedno mogoča,

\footnotetext{
${ }^{9}$ npr: državnih pomoči, pa tudi iz strukturnih in kohezijskega sklada EZ.
} 
- Stopnja regionalne razvitosti se v Sloveniji zaradi njene mozaične pestrosti spreminja na majhne razdalje. Regionalne disparitete tudi niso vedno istovetne $\mathrm{z}$ administrativnimi mejami in so pogosto odsev naravnih in drugih pogojev »neekonomske« narave (Ravbar, 1998). V tem primeru so razvojne poti območij s skupnimi razvojnimi problemi hitreje razrešljive mimo obstoječih institucionaliziranih (administrativnih) okvirov z iskanjem skupnih razvojnih ciljev, ukrepov in projektov na podlagi razvojnih, vendar neformalnih koalicij in instrumentov, kot jih ponuja regionalni management.

Regionalna politika je usmerjena na izboljševanje regionalnih in lokalnih okvirnih lokacijskih pogojev. Sestoji se iz svežnja drobnih ukrepov, čigar učinki se v idealnih razmerah dopolnjujejo. Cilj vsakega vrednotenja je povezan z ukrepi, ki odločilno vplivajo na učinke regionalne politike. Običajno razlikujemo tri področja in sicer: neposredne programske efekte, učinke konkurenčnosti in učinke izžarevanja, kot rezultat intenzitete medsebojnega gospodarskega mreženja s pomočjo prostorske selektivnosti učinkov (»Spill-over-efektov«), povečevanju intenzivnosti prenosa »Know-how-a« in stopnjevanju sposobnosti implementacije prenosa inovacij.

\section{Literatura}

Aydalot, P. 1986: Milieux innovateurs en Europe. Paris.

Becker, C., Ekert, S., 2004: Wissenschaftliche Begleitung des GA-Förderungsangebots Regionalmanagement, Berlin.

Bergmann, E., Jakubowski, P., 2001: Strategien der Raumordnung zwischen Kooperation und Wettbewerb. Informationen zur Raumentwicklung, H 8, s. 465-479.

Bühler, G., 1997: Regionalmarketing als Instrument der Landesplanung in Bayern. V: Goppel, K., Thieme, K., Troeger-Weiss, G.: Experimentale Geographie und Planung. Schriften zur Raumordnung und Landesplanung. Lehrstuhl für Sozial- und Wirtschaftsgeographie der Universität Augsburg, Augsburg, str. 323.336.

Fromhold-Eisebith, M. 1995: Das „Kreative Milieu“ als Motor regionawirtschaftlicher Entwicklung. Forschungstrends und Erfassungsmoeglichkeiten. Geographische Zeitschrift, letnik 83, zvezek 3-4, Stuttgart, str: 30-66.

Giessendorfer, Rahn, Stoiber, Meier, Siebert, 2003: Handbuch, »Erfolgreiches Regionalmanagement $«$, str. 1.

Gorlik, R., 1999: Regionalmarketing auf dem Prüfstand. Diplomsko delo na Tehniški Univerzi München - katedra za gospodarsko in socialno geografijo, München.

Knieling,J., Fürst,D., Danielzyk, R., 2003: Kooperetive Handlungsformen in der Regionalplanung; Zur Praxis der Regionalplanung in Deutschland. Dortmunder Vertrieb für Bauund Planungsliteratur, Dortmund.

Lucas, R., 2000: Von der regionalisierten Strukturpolitik zurnachhaltigen Regionalentwicklung. Regionale Politikkonzepte im Zeitalter der Globalisierung. Wuppertaler Papers, No 101, $30 \mathrm{~S}$. 
Maillat, D., (1992): The Inovation Process and the Role of the Milieu. V. D. Mailat in J. C. Perin (eds): Enterprises innovatrices et development territorial. GREMI. Neuchâtel: EDES, str: 3-20.

Obermaier, F., 1996: Management als Prinzip der Regionalplanung. Diplomsko delo na katedri za gospodarsko geografijo in regionalno planiranje na Univerzi v Bayreuthu, Bayreuth.

Ravbar, M., 1998: Ekonomsko-geografski pomen pojma "regionalne disparitete" in vloga leteh pri regionalnem razvoju. IB rev. Ljubljana, let. 32, št. 4/5, str. 9-19.

Ravbar, M., 2000: Vloga prostorskega planiranja v gospodarskem in regionalnem planiranju= Role of spatial planning in economic and regional development. Geographica Slovenica, 33/2, Ljubljana, 175-215 str.

Ravbar, M., Nared, J., 2003: Starting points for the monitoring and evaluation of regional policy in Slovenia = Izhodišča za spremljanje in vrednotenje regionalne politike $\mathrm{v}$ Sloveniji. Acta geogr. Slov., Ljubljana, letn. 43, št. 1, str. 53-83.

Strunz, J., 1998: Das Regionalmanagement - eine Aufgabe für Regionalplaner. Raumordnung und Raumforschung 5/6, ARL Hannover, str.435-448.

Sturm, P., (2000): Region Frankfurt/RheinMain, in: Informationen zur Raumentwicklung, Frankfurt, Heft 11/12. S. 705 ff.

Suchanek, A., (1998): Nachhaltigkeit und Wettbewerb. In: Zukunftsfähigkeit und Neoliberalismus, A. Renner und F. Hinterberger (Hrsg.), Baden-Baden, S. 204.

Troeger-Weiss, G., 1998: Regionalmanagement - Ein neues Instrument des Landes- und Regionalplanung. V: Goppel, K., Schaffer, F., Thieme, K., Troeger-Weiss, G.: Schriften zur Raumordnung und Landesplanung, Band 2, Augsburg.

Vrišer, I., 1999: Regionalni razvoj slovenskih pokrajin in občin. IB revija, let. 33, 2-3, str. 46-67.

Wiechmann, Th., 1998: Regionalmanagement auf dem Prüfstand. Bonn, str. 45

\section{REGIONAL MANAGEMENT - A CHALLENGE FOR POLITICS OF REGIONAL PLANNING}

\section{Summary}

The modern paradigm of regional development has two opposing ongoing processes: "globalization" as a reflection of the international complexity of economic and political streams and on the other hand "petty" local and/or regional political interest which are founded on sustainable development, local economies, balanced flows of production and the integration of economy and urban space into unified network of settlements. It is undisputable, that globalization is an irreversible process for the economies and the political development alike and connects, transforms and influences our social living. Various modern ideas of promoting regional development are in fact only the reflection of globalization. Hence the basic question: can we fruitfully develop methodologies and activities of regional planning in the "globalization era" and what are the chances of implementing concepts of different development policies. 
With the adoption of the "Stimulation of balanced regional development act" and the enforcement of other acts, the instruments in regional planning chanced significantly. New procedures in planning process were agreed upon. New institutions were formed, such as regional development agencies, technological parks, innovation centers, entrepreneur business zones, etc. But these are only a few perceivable activities that are broadening the extent of functioning and are challenging methods of regional planning.

Modern methods of accelerating the development are associated either with the search of endogen factors and/or stimulation of creative environment - that is with the creation of so called "learning regions" that are linked with new conceptions and interpretations such as: regional management, regional (urban) marketing, process moderation, communication and mediation planning, cooperative developmental promotion, etc... These conceptions are widening and opening new horizons of the planning procedures on the theoretical and practical level. This is also an excellent opportunity for relating spatial planning with regional development. Regional management as an intermediate stage holds the key role in participatory processes and the key role between spatial/regional planning, (entrepreneur) management and the promotion of regional development.

Regional development as the institutionalized form of promoting regional development is still a relatively new concept; consequently it has ever-changing procedures. Nevertheless it is still regarded as an important substance in the process of decision-making, especially when deciding on important developmental themes (projects) on the regional level. Regional management has an important connecting function and is therefore regarded as the source of regional cooperation of various actors. Its mission is also the transfer of objectives and measures of regional policies in a certain region.

Since the Slovenian planning literature did not assess the term regional management appropriately the following article presents new planning procedures and views of policies of regional development both in theory and in practice. By doing this we hope to fill the gaps and answer the following questions: what is regional management, what do we want to do with regional management and what are its basic tasks. 